\title{
An exploration study on building market oriented business
}

\author{
Naser Azad*, Mohammad Rikhtegar, Hamed Asgari, Hamid Bagheri and Hanieh Kasehchi
}

Department of Management, Islamic Azad University, South Tehran Branch, Tehran, Iran

\begin{tabular}{|c|c|}
\hline C H R O N I C LE & A B S T R A C T \\
\hline $\begin{array}{l}\text { Article history: } \\
\text { Received January 12, } 2013 \\
\text { Received in revised format } \\
9 \text { April } 2013 \\
\text { Accepted } 10 \text { April } 2013 \\
\text { Available online } \\
\text { April } 102013 \\
\text { Keywords: } \\
\text { Factor analysis }\end{array}$ & $\begin{array}{l}\text { Building market oriented business units is one of the key successes for creating competitive } \\
\text { economy. This paper presents an empirical investigation based on the implementation of factor } \\
\text { analysis to detect important factors influencing building market oriented business units. The } \\
\text { study designs a questionnaire including } 22 \text { questions and after verifying skewness of the data } \\
\text { the questions were reduced to } 18 \text { and the questionnaire was distributed among } 220 \text { experts. } \\
\text { Cronbach alpha was calculated as } 0.789 \text {, which is well above the minimum acceptable limit and } \\
\text { validates the results. The results of factor analysis reveal four major factors including } \\
\text { knowledge management, customer relationship management, creativity and flexibility. }\end{array}$ \\
\hline
\end{tabular}

(c) 2013 Growing Science Ltd. All rights reserved.

\section{Introduction}

Building a competitive business model plays an important role in the world especially in developing countries and it is essential to find important factors influencing it (Kohli \& Jaworski, 1990; Ruekert, 1992; Williams, 2010). During the past few years, there have been growing interests on detecting such factors, for instance, Polo Peña (2012) performed an investigation on market orientation adoption scale in rural tourism enterprises by studying the relationship between the characteristics of the enterprise and extent of market orientation adoption. Chen and Quester (2009) constructed a model of business performance based on customer value-defined market orientation. In their model, both firms' and customers' perspectives were involved for the development of the construct, using such dimensions as management support, employee efforts and customer satisfaction. They reported some evidence on the effects of a customer value-based market orientation on business performance, measured in terms of customer retention and disclosed three drivers of employees' effort to use market orientation from a value perspective.

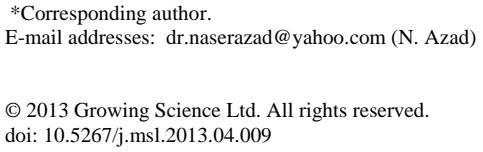


Market orientation is believed to be one of the most important components of building successful businesses. Wang et al. (2012) in a survey on some hotels reported that market orientation positively influences hotel performance. In their survey, market orientation had the mediating impact between total quality management (TQM) and hotel performance. In their survey, external environment factors virtually were moderator between TQM, market orientation and hotel performance, mode specifically when external environment factors greater changes were going to help to build relationship with customer, to enhance hotel performance and further to gain chance of hotel's survival.

Cheng and Krumwiede (2012) performed an investigation on the role of service innovation in the market orientation and new service performance linkage. They reported that the effect of competitor orientation on new service performance was fully mediated by radical service innovation. Hsieh et al. (2008) investigated the strategies market-oriented suppliers' implementation to accommodate customer requirements. They reported that market-oriented firms could satisfy their customers and prevent an overreliance on current relationships by emphasizing either flexibility or relationshipspecific adaptations.

Kim (2003) investigated the relationships between business performance of overseas subsidiary and market orientation, firm specific factors, competitive strategy, market specific factors and reported that market orientation could influence performance of overseas subsidiary larger than any other variables. Kumar et al. (2011) applied panel data constructed from the responses of repeatedly surveyed top managers at 261 firms regarding their firm's market orientation, along with objective performance measures, to study the impact of market orientation on performance over the period 1997-2005. The analyses revealed that market orientation had a positive impact on business performance in both the short and the long run.

Keneley and Hellier (2001) presented a market oriented approach to Australian undergraduate economics education. Narver and Slater (1990) investigated the effect of a market orientation on business profitability. According to Liu et al. (2003) "organizations with higher level of market orientation tend to be more learning-oriented, emphasize more on entrepreneurship, and be able to achieve higher level of organizational performance, than those with a lower level of market orientation". Singh and Ranchhod (2004) performed an investigation on market orientation and customer satisfaction by looking into some evidence from British machine tool industry.

\section{The proposed study}

The proposed study of this paper tries to find important factors impacting on market orientation using factor analysis. The study designed a questionnaire, distributed among 220 customers. The proposed study of this paper uses factor analysis to extract important factors.

Cronbach alpha was calculated as 0.789 , which is well above the minimum acceptable limit and validates the results. Kaiser-Meyer-Olkin Measure of Sampling Adequacy has been calculated as 0.684 and Bartlett's test of Sphericity approximation Chi-Square has also been calculated as 1702.262, which validate the overall results.

\section{The results}

The proposed study of this paper has determined four major factors using factor analysis and in this section, we present details of our findings. 


\subsection{The first factor: Knowledge management}

The first factor, "Knowledge management" includes four components including data collection, data generation, data distribution and data sharing. Table 1 summarizes details of our findings on this factor.

\section{Table 1}

The summary of factors associated with knowledge management

\begin{tabular}{lcccc}
\hline \multicolumn{1}{c}{ Option } & Factor weight & Eigenvalue & \% ofvariance & Accumulated \\
\hline Data collection & .838 & 4.252 & 23.623 & 23.623 \\
Data generation & .830 & & & \\
Data distribution & .778 & & & \\
Data sharing & .661 & & & \\
\hline Cronbach alph $=0.786$ & & & &
\end{tabular}

It is evident from the results of Table 1 that data collection is number one priority followed by data generation, data distribution and data sharing. Cronbach alpha has been calculated as 0.786, which validates the results of our survey.

\subsection{The second factor: Customer relationship management}

Customer relationship management is one of the most influential factors on the success of any business unit (Azad, \& Hashemi, 2012; Azad \& Hashemi, 2013). Azad and Hamdavipour (2012) in another study investigated the effects of packaging characteristics on consumer's purchasing confidence. Consumer relationship management is the second important item influencing building market orientation, which includes four factors summarized in Table 2 as follows,

Table 2

The summary of factors associated with customer relationship management

\begin{tabular}{lcccc}
\hline Option & Factor weight & Eigenvalue & \% ofvariance & Accumulated \\
\hline Strong perception from customers & .835 & 3.039 & 16.881 & 40.504 \\
Customer satisfaction & .737 & & & \\
Gathering information on customer & .726 & & & \\
Having close relationship with customers & .592 & & & \\
\hline Cronbach alph $=0.757$ & & &
\end{tabular}

According to the results of Table 2, having strong perception from potential customers is the most important factor followed by customer satisfaction, gathering information on customer while building close relationship with customers is the last priority.

\subsection{The third factor: Creativity}

Creativity is the third important factor influencing building market oriented businesses and it contains three factors, which are development of new service business, development of new technological business and having more innovative ideas (Azad et al., 2013). Table 3 shows details of our survey.

Table 3

The summary of factors associated with consumer materialism

\begin{tabular}{lcccc}
\hline Option & Factor weight & Eigenvalue & \% ofvariance & Accumulated \\
\hline Development of new service business & .829 & 2.054 & 11.412 & 51.916 \\
Development of new technological business & .825 & & & \\
Having more innovative ideas & .593 & & & \\
\hline
\end{tabular}


The results of Table 3 clearly indicate that development of new service business plays essential role on market development followed by development of new technological business.

\subsection{The fourth factor: Flexibility}

Flexibility is the last factor, which influences development of creating new businesses and it includes three factors summarized in Table 4 as follows,

\section{Table 4}

The summary of factors associated with consumer behavior

\begin{tabular}{lcccc}
\hline Option & Factor weight & Eigenvalue & \% ofvariance & Accumulated \\
\hline Coordination among various units & .871 & 1.271 & 7.059 & 58.975 \\
Appropriate reaction to market change & .829 & & & \\
Prediction of environmental business change & .49 & & & \\
\hline Cronbach alph $=0.626$ & & & & \\
\hline
\end{tabular}

Based on the results of Table 4, coordination among various units is the most important factor followed by appropriate reaction to market change and prediction of environmental business change.

\section{Discussion and conclusion}

Building market oriented business units is one of the key successes for creating competitive economy. In this paper, we have presented an empirical investigation based on the implementation of factor analysis to detect important factors influencing building market oriented business units. The results of factor analysis have revealed four major factors including knowledge management, customer relationship management, creativity and flexibility. Based on the results of our survey, we can present the following framework for our study.

Gathering, generating, distributing and sharing information

Having good perception from customer, getting good information and building close relationship with customer

Building new service and technological technology integrated with innovation

Having good coordination among various units, having good reaction with possible change and their prediction

Fig. 1. The structure of the proposed model

The first factor, "Knowledge management" includes four components including data collection, data generation, data distribution and data sharing and our survey suggested that data collection has been number one priority followed by data generation, data distribution and data sharing. Consumer relationship management is the second important item influencing building market orientation, which includes four factors where having strong perception from potential customers has been the most important factor followed by customer satisfaction, gathering information on customer and building close relationship with customers has been considered as the last priority.

Creativity has been the third important factor influencing building market oriented businesses and it contained three factors, including development of new service business, development of new technological business and having more innovative ideas. Our results have indicated that 
development of new service business plays essential role on market development followed by development of new technological business. Finally, flexibility is the last factor, which influences development of creating new businesses and it included three factors where coordination among various units has been the most important factor followed by appropriate reaction to market change and prediction of environmental business change.

\section{Acknowledgment}

The authors would like to thank anonymous referees for constructive comments on earlier version of this paper.

\section{References}

Azad, N., Hamdavipour, L. (2012). A study on effects of packaging characteristics on consumer's purchasing confidence. Management Science Letters, 2(1), 397-402.

Azad, N., Hashemi, S. (2012). A study on important factors influencing customer relationship management: A case study of Mobile service provider. Management Science Letters, 2(4), 11611164.

Azad, N., \& Hashemi, S. (2013). A study on important factors influencing customer relationship management: A case study of Mobile service provider. Management Science Letters, 3, 11611166.

Azad, N., Rostamnia, Y., \& Tazari, J. (2013). A study on important factors influencing innovation on computer hardware equipment: An empirical investigation using structural equation modeling. Management Science Letters, 3(4), 1291-1296.

Chen, S. C., \& Quester, P. G. (2009). A value-based perspective of market orientation and customer service. Journal of Retailing and Consumer Services, 16(3), 197-206.

Cheng, C. C., \& Krumwiede, D. (2012). The role of service innovation in the market orientationnew service performance linkage. Technovation, 32(7-8), 487-497.

Hsieh, Y. C., Chiu, H. C., \& Hsu, Y. C. (2008). Supplier market orientation and accommodation of the customer in different relationship phases. Industrial Marketing Management, 37(4), 380-393.

Keneley, M., \& Hellier, P. (2001). A market oriented approach to Australian undergraduate economics education: justification and explanation. Economic Papers: A journal of applied economics and policy, 20(2), 81-94.

Kim, Y. (2003). How will market orientation and environment and firm's character influence performance?. Cross Cultural Management: An International Journal, 10(4), 71-88.

Kohli, A. K., \& Jaworski, B. J. (1990). Market orientation: the construct, research propositions, and managerial implications. The Journal of Marketing, 54(2), 1-18.

Kumar, V., Jones, E., Venkatesan, R., \& Leone, R. P. (2011). Is market orientation a source of sustainable competitive advantage or simply the cost of competing?. Journal of Marketing, 75(1), 16-30.

Liu, S. S., Luo, X., \& Shi, Y. Z. (2003). Market-oriented organizations in an emerging economy: a study of missing links. Journal of Business Research, 56(6), 481-491.

Narver, J. C., \& Slater, S. F. (1990). The effect of a market orientation on business profitability. The Journal of Marketing, 20-35.

Polo Peña, A. I., Jamilena, D. M. F., \& Molina, M. Á. R. (2012). Validation of a market orientation adoption scale in rural tourism enterprises. Relationship between the characteristics of the enterprise and extent of market orientation adoption. International Journal of Hospitality Management, 31(1), 139-151.

Ruekert, R. W. (1992). Developing a market orientation: an organizational strategy perspective. International journal of research in marketing, 9(3), 225-245. 
Singh, S., \& Ranchhod, A. (2004). Market orientation and customer satisfaction: Evidence from British machine tool industry. Industrial Marketing Management, 33(2), 135-144.

Wang, C. H., Chen, K. Y., \& Chen, S. C. (2012). Total quality management, market orientation and hotel performance: the moderating effects of external environmental factors. International Journal of Hospitality Management, 31(1), 119-129.

Williams, B. K., Szaro, R. C., \& Shapiro, C. D. (2010). Adaptive Management: The US Department of the Interior Technical Guide. US Department of the Interior. 